\title{
Analysis of Satisfaction of University e-Learning Classes
}

\author{
Youngmi Moon \\ Associate professor, Department of Social Welfare \\ Baekseok Arts University, South Korea \\ Email: youngmoon33 [AT] daum.net
}

\begin{abstract}
This study, therefore, aims to propose a direction for the future e-learning class, by analyzing the satisfaction with e-learning class.

It also administered questionnaires to 96 freshmen at universities located in Seoul, from Jun. 22 to Jun. 30, 2020, and used a total of 92 copies in the finally analysis. From the findings above, following suggestions for the quality improvement of e-learning class in general universities can be summarized:

First, it needs to prioritize the establishment of stable and available e-learning systems in schools. Second, professors should quickly adapt to e-learning class, a new paradigm of education. Third, student should primarily acquire basic abilities to use computers, recognize that self-directed learning is the core of university education and make effort to escape from learning by rote, which had been conducted from elementary to high schools. In addition, they should reasonably judge what a method is desirable for enhancing their learning performance.
\end{abstract}

Keywords----e-learning, Class satisfaction

\section{I. NECESSITY OF STUDY}

As the world greets the era of the 4th Industrial Revolution, new changes are taking place in the society at large. The educational field is no exception, because it is called for a new educational paradigm and is pursuing change. Under such circumstances, every sector of society was forced into an untact, online or home-based environment for studying and working due to the COVID-19, which caused a global pandemic in 2020. Now, coping with these situations is no longer a matter of choice but an essential, and is even becoming the only way of survival. Universities, in particular, are facing a transition period, having to break away from the existing high-cost educational system based on physical campus and adopt an educational paradigm that effectively responds to globalization and informatization (Jeong \& Jeon, 2002). They have to take on a new challenge of assuming the responsibility of e-learning education because of the unexpected war against virus.

E-learning education breaks away from the existing classroom classes that are carried out face-to-face: It can be described as a personalized educational environment in which students learn at the time and place they want. E-learning education utilizes the advantages of technology to facilitate the application of information using multimedia, learner-centered learning, sharing of information and resources, and updating of information or data, and thereby enables education applying various teaching-learning methods (Kang, 2002).

However, many universities are shoved to implement e-learning classes without preparation, giving rise to intense dissatisfaction among students because of poor learning content and insufficient technical support. Despite this situation, there is very little empirical research on this matter. Therefore, this study aims to determine what aspects are found satisfactory among students even under the poor environment and what their ultimate expectations are, drawing basic research results for quick solutions to the current problem, and to suggest the direction of future e-learning classes.

\section{LITERATURE REVIEW}

\section{1. e-learning}

According to Article 2 (Definitions) of the Act on Development of E-learning Industry and Promotion of Utilization of Elearning (partially amended on October 31, 2017), e-learning is stipulated as 'learning by means of electronic tools, information and communications, electric wave or broadcasting technology.' In the field of education engineering, the concept of e-learning is defined as 'an educational training method where learners lead the learning goals and methods for themselves using information and communication technology' or as 'a series of learning activities that restructure digitalized learning contents into a learner's cognitive structure in a network-based environment' (Ministry of Commerce, Industry and Energy et al., 2005).

Until now, the concept of e-learning have been used with various terms, among which the most common ones are online education, virtual education, cyber education, internet-based education, web-based education, web-based learning, distance 
education, online education, and e-learning (Lee, 2002:15). Accordingly, this study uses the term e-learning, which is widely used most recently.

\subsection{Previous studies on learning satisfaction of e-learning}

Research related to e-learning began in the 1980s, when the computer communication system started to be fully utilized in educational setting, and mainly aimed at identifying the factors that influence the learning effects e-learning. Among studies related to learning satisfaction, which is relevant to this study, the following studies were frequently cited in subsequent studies.

Jae-sam Jung and Gyu-Yeon Lim (2000) are a study to find out the main factors related to learner's participation, achievement, and satisfaction in web-based discussion. appear.

Choi Kwang-shin and Noh Jin-deok (2002) examined various factors that affect student satisfaction, and in particular, in e-learning classes, like face-to-face classes, suggested that interaction with instructors should be activated in various ways to increase learning satisfaction. .

In-Keun Jung and Jo Jung-Yong (2004) studied e-learning and the relationship formation between learners, and this study particularly emphasized the moderating effect of learning patterns.

Based on the above-mentioned previous studies, it can be stated that learning satisfaction and outcome from e-learning depend on various factors, which mainly consist of personal and system-related matters.

Because the intended subjects of this study were not students of cyber universities that are equipped with e-learning facilities but students attending general universities that implemented e-learning classes without preparation due to the COVID-19 pandemic in 2020, this study focused on a preliminary research exploring the meaning of respective factors and the relationship between factors rather than clarifying the specific factors that influence learning satisfaction of elearning.

\section{METHODS AND RESULTS}

\subsection{Methods}

This study conducted the satisfaction test which the researcher created by sincerely translating the test kit that Lee Seongju and Gwang Jaehwan(2011) used in their thesis and adjusted it to the actual Korean universities by consulting three professionals. It also administered questionnaires to 96 freshmen at universities located in Seoul, from Jun. 22 to Jun. 30 , 2020, and used a total of 92 copies in the finally analysis.

\subsection{Results}

\subsubsection{Frequency Analysis}

The distribution of the subjects was examined to find that the ratio of female(68.1\%) was higher than that of males and the ratio of the subjects under 29 was highest $(85.7 \%)$. Compared with students in other universities, the ratio of those older than 60 accounted for as high as $9.9 \%$ in the university. Since such old people were not skilled at computers, it may be possible to predict their difficulty in entering e-learning class. In addition, most of students( $\mathrm{n}=82)$ marked middle or low, in a scale of their computer skills. Contrary to our expectations, there are students $(5.28 \%)$ who have not experienced elearning class.

On the other hand, students responded that lecture (52.7\%) and assignment $(29.7 \%)$ were useful class, while the ratio of those, who responded that debate which were often used in class was useful, was relatively low (2.2\%). This result should be considered when the future class is organized. In addition, 53 students responded that the class time less than 30 minutes was proper, while 38 students responded that the class time of 30 minutes-1 hour was adequate, compared with face-toface class, indicating no significant difference between them.

To the question, 'whether teaching methods were appropriate', the highest ratio of students(42.9\%) responded 'yes'. To the question about the stability of systems, the highest ratio of them $48.4 \%$ responded that it was moderate. To the question about the convenience of systems, the highest ratio of students(39,7\%) responded that they were convenient. 
Table 1: Frequency Analysis

\begin{tabular}{|c|c|c|c|}
\hline \multicolumn{2}{|l|}{ division } & \multirow{2}{*}{$\begin{array}{l}\text { Frequency } \\
29\end{array}$} & \multirow{2}{*}{$\begin{array}{l}\text { Percentage(\%) } \\
31.9\end{array}$} \\
\hline & Male & & \\
\hline Gender & Female & 62 & 68.1 \\
\hline \multirow{4}{*}{ Age } & Under 29 & 78 & 85.7 \\
\hline & $30-39$ & 3 & 3.3 \\
\hline & $40-59$ & 1 & 1.1 \\
\hline & Over 60 & 9 & 9.9 \\
\hline \multirow{3}{*}{ Computer level } & High level & 9 & 9.9 \\
\hline & middle level & 47 & 51.6 \\
\hline & low level & 35 & 38.5 \\
\hline \multirow{2}{*}{ E-learning class experience } & have & 43 & 47.2 \\
\hline & none & 46 & 52.8 \\
\hline \multirow{5}{*}{ Useful class content } & lecture & 48 & 52.7 \\
\hline & assignment & 10 & 11 \\
\hline & $\mathrm{Q} \& \mathrm{~A}$ & 4 & 4.4 \\
\hline & debate & 2 & 2.2 \\
\hline & Related video & 27 & 29.7 \\
\hline \multirow{2}{*}{ Suitable class time(Per hour) } & 30 minutes less & 53 & 58.2 \\
\hline & 30 minutes _ 1 hour less & 38 & 41.8 \\
\hline \multirow{5}{*}{ Appropriateness of class } & very good & 11 & 12.1 \\
\hline & good & 39 & 42.9 \\
\hline & usually & 34 & 37.4 \\
\hline & complaining & 3 & 3.3 \\
\hline & Very complaining & 4 & 4.4 \\
\hline \multirow{5}{*}{ Stable system } & very good & 3 & 3.3 \\
\hline & good & 32 & 35.1 \\
\hline & usually & 44 & 48.4 \\
\hline & complaining & 7 & 7.7 \\
\hline & Very complaining & 5 & 5.5 \\
\hline \multirow{5}{*}{ System convenience } & very good & 5 & 5.5 \\
\hline & good & 36 & 39.7 \\
\hline & usually & 34 & 37.4 \\
\hline & complaining & 11 & 12 \\
\hline & Very complaining & 4 & 4.4 \\
\hline \multirow{2}{*}{ Preferred way } & Pre-recording & 81 & 89 \\
\hline & Real-time class & 10 & 11 \\
\hline \multirow{5}{*}{ Interaction with professor } & very good & 11 & 12.1 \\
\hline & good & 45 & 49.5 \\
\hline & usually & 27 & 29.7 \\
\hline & complaining & 4 & 4.4 \\
\hline & Very complaining & 4 & 4.4 \\
\hline \multirow{5}{*}{ Class satisfaction } & very good & 7 & 7.7 \\
\hline & good & 41 & 45.1 \\
\hline & usually & 35 & 38.5 \\
\hline & complaining & 4 & 4.4 \\
\hline & Very complaining & 4 & 4.4 \\
\hline \multirow{4}{*}{ Advantages of online classes } & Autonomous course time & 64 & 70.3 \\
\hline & Reduce commuting time and cost & 14 & 15.4 \\
\hline & Concentration & 12 & 13.2 \\
\hline & Etc & 1 & 1.1 \\
\hline \multirow{4}{*}{$\begin{array}{l}\text { Disadvantages of online } \\
\text { classes }\end{array}$} & Difficulty using computers & 12 & 13.2 \\
\hline & Lack of exchange between professors and students & 45 & 49.4 \\
\hline & Cannot use school facilities & 24 & 26.4 \\
\hline & Etc & 10 & 11 \\
\hline \multicolumn{2}{|l|}{ Total } & 91 & 100.0 \\
\hline
\end{tabular}


The most notable question was about e-learning class methods, and the majority of students (89\%) preferred the prerecording format.

Among all students, $45.1 \%$ responded that their satisfaction with the whole class was high, while $38.5 \%$ responded that it was moderate.

Finally, 70,3\% of students responded that the strongest advantage of e-learning was to be able study during free time, while $48.4 \%$ of them responded that the biggest disadvantage was the inadequate exchange between professors and students. Although the results of this study are partly similar with those of previous studies, there were some differences between them, so a deeper study should be conducted in the future.

\subsubsection{Correlations}

There were no variables which have significant correlations with class satisfaction, probably because this year was a special period in which all of schools, professors and students engage in e-learning class, without any preparations. Since such a situation may continue in the future, a deeper study is required to examine factors influencing the class satisfaction. 
Table2: Correlations

\begin{tabular}{|c|c|c|c|c|c|c|c|c|c|c|c|c|c|c|}
\hline & Age & Gender & $\begin{array}{l}\text { Computer } \\
\text { level }\end{array}$ & \begin{tabular}{|l}
$\begin{array}{l}\text { E-learning } \\
\text { class } \\
\text { experience }\end{array}$ \\
\end{tabular} & $\begin{array}{l}\text { Useful class } \\
\text { content }\end{array}$ & $\begin{array}{l}\text { Suitable } \\
\text { class time }\end{array}$ & $\begin{array}{l}\text { Appropriateness } \\
\text { of class }\end{array}$ & $\begin{array}{l}\text { Stable } \\
\text { system }\end{array}$ & $\begin{array}{l}\text { System } \\
\text { convenience }\end{array}$ & $\begin{array}{l}\text { Preferred } \\
\text { way }\end{array}$ & $\begin{array}{l}\begin{array}{l}\text { Interaction } \\
\text { with } \\
\text { professor }\end{array} \\
\end{array}$ & $\begin{array}{l}\text { Class } \\
\text { satisfaction }\end{array}$ & \begin{tabular}{|l|} 
Advantages \\
of online \\
classes
\end{tabular} & $\begin{array}{l}\text { Disadvantages } \\
\text { of } \quad \text { online } \\
\text { classes }\end{array}$ \\
\hline Age & 1 & & & & & & & & & & & & & \\
\hline Gender & 0.056439484 & 4 & & & & & & & & & & & & \\
\hline Computer level & 0.129431748 & $8-175376254$ & 4 & & & & & & & & & & & \\
\hline $\begin{array}{l}\text { E-learning class } \\
\text { experience }\end{array}$ & 0.298654098 & 80.142614139 & 90.227947198 & & & & & & & & & & & \\
\hline $\begin{array}{ll}\begin{array}{l}\text { Useful } \\
\text { content }\end{array} & \text { class } \\
\end{array}$ & 0.050195971 & 0.014216546 & $6-0.01680545$ & 0.064366937 & & & & & & & & & & \\
\hline $\begin{array}{l}\text { Suitable class } \\
\text { time }\end{array}$ & 0.088256387 & 70.100896628 & 8 & $8^{0.016659959}$ & 90.124493638 & 1 & & & & & & & & \\
\hline $\begin{array}{l}\text { Appropriateness } \\
\text { of class }\end{array}$ & s 0.139924988 & 80.079896999 & $9[0.128608792$ & $2^{0.117222333}$ & 30.04482546 & {$[0.150711561$} & & & & & & & & \\
\hline Stable system & -0.10687666 & 0.036170447 & 0.182975944 & $4^{-0.08134079}$ & 0.076252819 & 0.215106651 & 0.405342952 & 1 & & & & & & \\
\hline $\begin{array}{l}\begin{array}{l}\text { System } \\
\text { convenience }\end{array} \\
\end{array}$ & 0.062162926 & 60.018243765 & $5^{-0.13772452}$ & 0.151066018 & 8.125402091 & $\mid 0.187413326$ & 0.39807504 & 0.843909026 & 1 & & & & & \\
\hline Preferred way & 0.134667204 & $4-0.12080782$ & 0.017490316 & 60.165555046 & 60.122999498 & 0.209267407 & $7-0.025917897$ & - 0.007002381 & 0.059917883 & & & & & \\
\hline $\begin{array}{l}\text { Interaction with } \\
\text { professor }\end{array}$ & 0.122498613 & 30.013633606 & 60.043424621 & 0.15440368 & 0.103664805 & 0.171757061 & 0.582646038 & 0.357486835 & 0.31877552 & 0.049543443 & & & & \\
\hline $\begin{array}{l}\text { Class } \\
\text { satisfaction }\end{array}$ & 0.111854205 & 50.019091723 & 30.054158333 & $3^{0.106532838}$ & 80.024133236 & 0.231969076 & 0.787949644 & 0.475878233 & 0.475009662 & 0.079522672 & 0.623999583 & $3 \mid 1$ & & \\
\hline $\begin{array}{l}\text { Advantages of } \\
\text { online classes }\end{array}$ & 0.164074947 & 0.064128201 & 0.061928612 & 20.062976131 & 10.012045035 & 0.179519452 & 0.136291534 & 0.22836203 & 0.109374236 & 0.133030235 & 0.17089109 & 0.17271022 & 1 & \\
\hline $\begin{array}{l}\text { Disadvantages } \\
\text { of online classes }\end{array}$ & s-0.08263958 & 0.079464357 & 70.402839847 & 70.206166543 & 30.072492056 & 0.027511067 & 7- -0.170064989 & 0.017404317 & 0.051745269 & 0.078357675 & 0.017812633 & 30.064420057 & 70.203 & \\
\hline
\end{tabular}




\section{IMPLICATIONS}

The purpose of this study is to provide basic data for better class to universities in many difficult circumstances, though they should progress e-learning class, professors in charge of class and students who would take the class.

To this end, it administered questionnaires about online class to 96 freshmen at a university located in Seoul.

The main findings are as follows:

Students responded that lecture $(52.7 \%)$ and assignment $(29.7 \%)$ were useful class, while the ratio of those, who responded that debate which were often used in class was useful, was relatively low $(2.2 \%)$. This result should be considered when the future class is organized. In addition, 53 students responded that the class time less than 30 minutes was proper, while 38 students responded that the class time of 30 minutes- 1 hour was adequate, compared with face-to-face class, indicating no significant difference between them.

Among all students, $45.1 \%$ responded that their satisfaction with the whole class was high, while $38.5 \%$ responded that it was moderate, and $70,3 \%$ of students responded that the strongest advantage of e-learning was to be able study during free time, while $48.4 \%$ of them responded that the biggest disadvantage was the inadequate exchange between professors and students.

From the findings above, following suggestions for the quality improvement of e-learning class in general universities can be summarized as:

- $\quad$ First, it needs to prioritize the establishment of stable and available e-learning systems in schools. Although many schools began e-learning without any preparations in COVID-19 related circumstances, in this year (2020), it would be possible to attract students and prevent students' migration, only if schools make an investment in it, from a long view, since we may continuously face similar circumstances.

- Second, professors should quickly adapt to e-learning class, a new paradigm of education. The contents of class would be strictly limited, if they adhere to the existing class methods. They should strive to meet students' various needs by properly using infinite advantages of online environment. In particular, students desire for the interactions between professors and students, so it is necessary to examine how to meet such needs.

- Third, student should primarily acquire basic abilities to use computers, recognize that self-directed learning is the core of university education and make effort to escape from learning by rote, which had been conducted from elementary to high schools. In addition, they should reasonably judge what a method is desirable for enhancing their learning performance. For example, there was a contrasting factor in this study: the majority of students preferred prerecording format, while students indicated the lack of interactions between professors and students as the most serious weakness of e-learning class, since there are relatively fewer matters dealt with through the interactions, if class is prerecorded. Real-time e-learning class is required for such interaction, but students should deeply reflect that many students cannot have consistent thoughts, for themselves.

In order to promote successful e-learning class, three parties including schools, professors and students should rightly recognize e-learning, a new circumstance and consider and challenge the areas for which they should be responsible.

\section{REFERENCES}

- Kang Myung-hee (2002), “Analysis of Class Effect Factors in Web-based Virtual Classes in Parallel University Practical Classes: A Case Study”, Advanced Research, Vol. 13, No. 2

- Seongju Lee, Jaehwan Kwon (2011), The Influence of Online Learning Situation and Learner's Learning Style on Blended Learning Satisfaction, Journal of Internet Information Society, Vol. 12, No. 6

- Lee In-sook. (2002). 「e-learning-a new paradigm in cyberspace $\lrcorner$. Seoul: Mooneumsa.

- Daeyul Jeong and Ki Jeon (2002), "A Study on the Instructor's Demand Analysis for Establishing the Strategic Plan for the Virtual University System: Focusing on the Case of K University" Research in Management Information Science, Vol. 4, No. 1

- In-Keun Jung.Jeong-Yong Jo (2004). On the factors affecting satisfaction and affinity of e-Learning $\ulcorner$ Korea Management Information Society Spring Academic College Journal of thesis $\lrcorner$, 3-9

- Jeong In-seong. (1997). Development of an online virtual university model based on constructivism. Educational Engineering Research $\lrcorner, 13(2): 315-338$.

- Jae-sam Jung and Gyu-Yeon Lim. (2000) Regarding learners' participation, achievement, and satisfaction in webbased discussions Analysis of the effects of factors. 「 $\ulcorner$ Educational Engineering Research $\lrcorner, 16(2): 107-135$

- Choi Kwang-shin and No Jin-deok (2002). Moderating Effects of Interaction between Student and Teacher= A Study on Learning, System, and Administrative Variables Influencing Students' Satisfaction in Cyber-Education 
Focusing on the effect of interaction with professors and professors. Journal of Korean Information Strategy Society, 5(2): 23-52.

- Tae-in Han and Deok-Hoon Kwak. (2006). $\ulcorner$ E-Learning You-Learning $\lrcorner$. Seoul: Korea Industry-Academic Cooperation Complex

- Ministry of Trade, Industry and Energy, Information and Communication Industry Promotion Agency (2015). 2015 e-learning industry survey. Chungcheong: Information and Communication Industry Promotion Agency. 